\title{
Glutamate-Evoked Release of Arachidonic Acid from Mouse Brain Astrocytes
}

\author{
N. Stella, M. Tencé, J. Glowinski, and J. Prémont \\ Laboratoire de Neuropharmacologie, INSERM U114, Collège de France, 75231 Paris Cedex 05, France
}

\begin{abstract}
Brain astrocytes in primary culture from the rat or the mouse have been shown to possess ionotropic and metabotropic glutamatergic receptors. The activation of both types of receptors is responsible for a rise in the cytosolic concentration of calcium, while the stimulation of metabotropic receptors induces the accumulation of inositol phosphates. In the present study, it is demonstrated that in striatal astrocytes from mouse embryos, glutamate evokes a release of arachidonic acid. The nonionotropic receptors involved in this effect appeared to be pharmacologically distinct from those coupled to phospholipase $C:$ (1) glutamate displayed different dose-response curves for the production of inositol phosphates (biphasic: $\mathrm{EC}_{50}=25$ and $300 \mu \mathrm{M}$ ) and the release of arachidonic acid (monophasic: $\mathrm{EC}_{50}=200 \mu \mathrm{M}$ ); (2) LL(+)2-amino-4-phosphonobutyric acid (AP4) only antagonized the glutamate-evoked release of arachidonic acid without altering the production of inositol phosphates; (3) when used at a concentration of $0.1 \mathrm{~mm}$, quisqualate induced a higher formation of inositol phosphates than glutamate $(2 \mathrm{mM})$ while, in contrast to glutamate, it only weakly stimulated arachidonic acid release when used either at $0.1 \mathrm{mM}$ or $1 \mathrm{mM} . L(+)$ 2-amino-3-phosphonopropionic acid (AP3) suppressed both responses.
\end{abstract}

The glutamate-evoked release of arachidonic acid seems to be oppositely regulated by protein kinases $A$ and $C$. Indeed, the stimulation of adenylate cyclase by the $\beta$-adrenergic agonist isoproterenol, vasoactive intestinal peptide, or pretreatment of striatal astrocytes with cholera toxin decreased the glutamate-evoked release of arachidonic acid. In contrast, ATP, which markedly stimulated inositol phosphate production, strongly potentiated the glutamate-evoked release of arachidonic acid. An activation of protein kinase C could be involved in this potentiation since it was reproduced by the phorbol ester phorbol 12-myristate 13-acetate (PMA), and depressed by staurosporine or when protein kinase $C$ was desensitized by long-term pretreatment with PMA.

[Key words: astrocyte, arachidonic acid, inositol phosphates, glutamate, metabotropic receptor, purinergic receptor]

\footnotetext{
Received May 10, 1993; revised July 5, 1993; accepted July 15, 1993

This study was supported by grants from INSERM (Institut National de la Santé et de la Recherche Médicale), Direction des Recherches Etudes et Techniques (DRET, contrat 90/078) and Rhône Poulenc Rorer. N.S. is supported by Fonds National Suisse 31-26427.89.

Correspondence should be addressed to Dr N. Stella, Laboratoire de Neuropharmacologie, INSERM U114, Collège de France, 11 Place M. Berthelot, 75231 Paris Cedex 05, France.

Copyright (C) 1994 Society for Neuroscience $0270-6474 / 94 / 140568-08 \$ 05.00 / 0$
}

Evidence is accumulating that astrocytes are important in controlling the ionic and chemical environment of neurons. This regulation seems to be mediated, in part, by direct interactions of neurotransmitters with glial receptors (Murphy and Pearce, 1987; Teichberg, 1991) leading to various cellular responses, including ion transport and changes in membrane potential (Newman et al., 1984; Nowak et al., 1987; Enkvist et al., 1989). Moreover, some neurotransmitters such as glutamate are taken up and released from astrocytes (Pares-Herbuté et al., 1988; Kimelberg et al., 1990; Martin, 1992). Of particular interest is the observation that glutamate uptake into glial cells (Müller cells) from the salamander retina (Barbour et al., 1989) and into astrocytes from the rat cerebral cortex is inhibited by arachidonic acid (AA) (Volterra et al., 1992). Moreover, the formation of AA in glial cells can be modulated by neurotransmitters. Indeed, we have recently reported that the combined activation of $\alpha_{1}$-adrenergic receptors and of either $\mathrm{Al}$ adenosine or somatostatin receptors stimulates the release of AA from cultured striatal astrocytes of mouse embryos (Marin et al., 1991; El-Etr et al., 1992). In addition, our experiments have suggested that released AA increases the accumulation of external glutamate by blocking its reuptake process and that, in turn, glutamate, by acting on metabotropic receptors, enhances the production of inositol phosphates (IPs) in striatal astrocytes through a paracrine process (El-Etr et al., 1989, 1992; Marin et al., 1991). However, the subtype of metabotropic receptor involved in this mechanism remains to be identified. Indeed, among the six metabotropic glutamatergic receptors presently cloned, only the mGluR3 mRNA has been shown to be present in glial cells from different brain structures. Moreover, when transfected in Chinese hamster ovary cells, this mGluR 3 receptor has only been found to be negatively coupled to a cAMP-generating system sensitive to pertussis toxin (PTX). On the contrary, the stimulation of the transfected neuronal mGluR1 receptor enhances IP formation, intracellular calcium mobilization, and release of AA (for review, see Nakanishi, 1992).

In the present study, it will be shown that glutamate also induces the release of AA in cultured astrocytes from different brain structures by activating nontypical glutamatergic receptors. In addition, the receptors involved in this response are distinct from those responsible for the glutamate-evoked production of IPs.

\section{Materials and Methods}

\section{Materials}

Glutamate, fatty acid-free bovine serum albumin (BSA), thimerosal, kainate, 8-bromo-cAMP (8-Br-cAMP), polyornithine (MW 40,000), phorbol 12-myristate 13-acetate (PMA), 4 $\alpha$-PMA, 1-(5-isoquinolinesulfonyl)-2-methyl-piperazine (H7), $N$-[2-(methylamino)ethyl]-5-iso- 


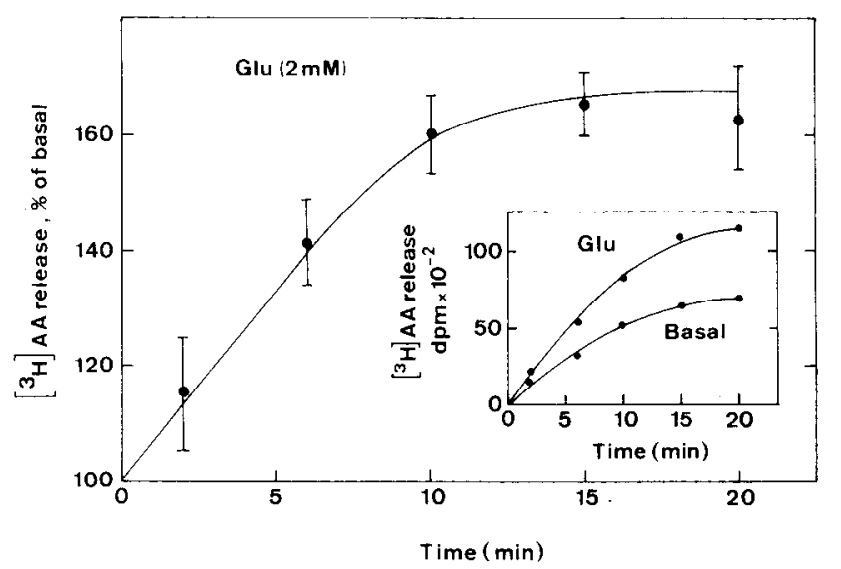

Figure 1. Time course of the glutamate-evoked release of ${ }^{3} \mathrm{H}$-AA. Striatal astrocytes were incubated for various times with glutamate (2 $\mathrm{mm}$ ) and ${ }^{3} \mathrm{H}$-AA release was estimated as described in Materials and Methods. Results are expressed either as percentage of ${ }^{3} \mathrm{H}$-AA release of basal values $(100 \%)$ or as $\mathrm{dpm} \times 10^{-2}$ of ${ }^{3} \mathrm{H}$-AA released in the absence (basal) or presence of glutamate $(G l u)$ (inset). Data are the mean \pm SEM of three determinations. Two independent other experiments yielded similar results

quinolinesulfonamide (H8), mepacrine, $\beta$-methyl-nI-aspartic acid $(\beta$ MAA), isoproterenol, and cholera toxin (CTX) were obtained from Sigma; $(1 S, 3 R)$-1-aminocyclopentane-1,3-dicarboxylic acid ( $t$-ACPD), $\mathrm{L}(+)$-2-amino-3-phosphonopropionic acid ( $\mathrm{PP} 3)$, L-trans-pyrrolidine2,4-dicarboxylic acid ( $t$-PDC), 6-cyano-7-nitroquinoxaline-2,3-dione (CNQX),

6,7-dinitroquinoxaline-2,3-dione (DNQX), and L(+)-2-amino-4-phosphonobutyric acid (AP4), from Tocris Neuramin; (+)-quisqualate, DL-2-amino-5-phosphonopentanoic acid (AP5), ibotenate, and $(5 R, 10 S)$ (+)-5-methyl-10,11-dihydro-5H-dibenzo[a,d]cyclohepten-5,10-imine hydrogen maleate (MK801), from Research Biochemicals Incorporated; staurosporine, from Calbiochem; RG 80267, from Rorer Central Research; pertussis toxin (PTX), from List Biological Laboratories; adenosine desaminase (ADA), glutamate-pyruvate transaminase (GPT), and pyruvate, from Boehringer, Mannheim, Germany; vasoactive intestinal peptide (VIP), from Bachem (Budenhorf, Switzerland); ${ }^{3} \mathrm{H}$-arachidonic acid $\left({ }^{3} \mathrm{H}-\mathrm{AA} ; 200 \mathrm{Ci} / \mathrm{mmol}\right)$ and myo- ${ }^{3} \mathrm{H}$-inositol $(17 \mathrm{Ci} /$ $\mathrm{mmol}$ ), from Amersham; Minimal Essential Medium (MEM) and F-12 nutrient, from GIBCO (Eragny, France); and Nu-Serum, from Collaborative Research.

\section{Methods}

Cell culture. Mice were killed by prolonged exposure to a high concentration of carbon dioxide. Embryos were removed from the uterus and placed in phosphate-buffered saline supplemented with glucose ( $33 \mathrm{~mm}$ ). Primary cultures of glial cells were prepared as previously described (ElEtr et al., 1989). Briefly, the striatum, cerebral cortex, and hippocampus were removed from 16-d-old Swiss mouse embryos and the cerebellum from 2-d-old newborn mice (Iffa Credo, Lyon, France). Mechanically dissociated cells were plated into 12 -well Falcon culture dishes $\left(3 \times 10^{5}\right.$ cells per well) previously coated with $1.5 \mu \mathrm{g} / \mathrm{ml}$ polyornithine. The culture medium was composed of a mixture of minimum essential medium (MEM) and F-12 nutrient (1:1) supplemented with $33 \mathrm{~mm}$ glucose, 2 mm glutamine, $13 \mathrm{~mm}$ sodium bicarbonate, $20 \mathrm{~mm}$ HEPES buffer (pH 7.4), and $10 \% \mathrm{Nu}-$ Serum. Cells were cultured at $37^{\circ} \mathrm{C}$ for $18-21 \mathrm{~d}$ in a humidified atmosphere of $95 \%$ air and $5 \% \mathrm{CO}_{2}$. The culture medium was first changed on day 7 and thereafter twice a week. On day 12 , cytosine arabinoside $(2 \mu \mathrm{M})$ was added for $48 \mathrm{hr}$ to avoid the formation of cell multilayers and the proliferation of microglial cells. Under these conditions, after $21 \mathrm{~d}$ in culture, more than $95 \%$ of the cells were stained by the indirect fluorescence technique using a rabbit antibody against glial fibrillary acid protein (GFAP) (Dakopatt, Denmark). The remaining $5 \%$ of the cells could be immature glioblasts, which are known to be unlabeled by GFAP antibodies (Eng, 1985). No staining was observed using the monoclonal anti-mouse macrophage antibody (anti-MAC-1, Serotec, Paris, France) which has been found
Table 1. Glutamate-induced release of ${ }^{3} \mathrm{H}-\mathrm{AA}$ in cultured astrocytes from various brain regions

\begin{tabular}{ll} 
Brain areas & $\begin{array}{l}\text { Glu (2 mM)-induced } \\
\text { release of }{ }^{3} \mathrm{H}-\mathrm{AA} \\
\text { (\% of basal) }\end{array}$ \\
\hline Striatum & $165 \pm 5$ \\
Cortex & $186 \pm 12$ \\
Hippocampus & $183 \pm 10$ \\
Cerebellum & $174 \pm 11$
\end{tabular}

Results are expressed as percentage of the corresponding basal value (100\%). Data are the mean \pm SEM of three independent experiments performed in triplicate.

to detect $>95 \%$ of microglial cells originating from mice (Frei et al., 1987).

Measurement of ${ }^{3} \mathrm{H}-\mathrm{A} A$ release. ${ }^{3} \mathrm{H}-\mathrm{AA}$ release was estimated as described by Tencé et al. (1992). Briefly, astrocytes cultured in 12-well dishes were incubated overnight with ${ }^{3} \mathrm{H}-\mathrm{AA}(1 \mu \mathrm{Ci} / \mathrm{ml})$ added to the culture medium. When stated, cells were pretreated with either pertussis toxin or cholera toxin added to the culture medium. After washing three times with a Krebs phosphate buffer (in mM: $\mathrm{NaCl}, 120 ; \mathrm{NaH}_{2} \mathrm{PO}_{4}$, $15.6 ; \mathrm{KCl}, 4.8 ; \mathrm{MgSO}_{4}, 1.2 ; \mathrm{CaCl}_{2}, 1.0 ;$ glucose, $\left.33 ; \mathrm{pH}, 7.4\right)$ containing fatty acid-free bovine serum albumin $(1 \mathrm{mg} / \mathrm{ml})$, cells were preincubated for $10 \mathrm{~min}$ with thimerosal $(50 \mu \mathrm{M})$. They were then exposed for $15 \mathrm{~min}$ (except when otherwise stated) at $37^{\circ} \mathrm{C}$ to the effectors in the same medium supplemented with adenosine deaminase (1 $\mathrm{IU} / \mathrm{ml}$ ). Incubation media were centrifuged at $100 \times g$ for $5 \mathrm{~min}$ and the radioactivity was estimated in the supernatants. As previously described (Delumeau et al., 1991), HPLC analysis indicated that more than $95 \%$ of the released radioactivity is recovered in a peak having the same retention time as authentic AA.

Measurement of ${ }^{3} H-I P$ formation. Cells, grown in the same conditions, were incubated for $18 \mathrm{hr}$ in the presence of myo ${ }^{-3} \mathrm{H}$-inositol $(2 \mu \mathrm{Ci} / \mathrm{ml})$ added to the culture medium. The accumulation of ${ }^{3} \mathrm{H}$-IPs was estimated as previously described (El-Etr et al., 1989). Briefly, cells were preincubated for $10 \mathrm{~min}$ in Krebs phosphate buffer supplemented with lithium $(10 \mathrm{~mm})$. Effectors were then added for $15 \mathrm{~min}$ in the presence of adenosine deaminase $(1 \mathrm{IU} / \mathrm{ml})$. The incubation $(1 \mathrm{ml})$ was stopped by adding successively $0.1 \%$ Triton $\mathrm{X}-100$ in $0.1 \mathrm{~m} \mathrm{NaOH}(400 \mu \mathrm{l})$ and $0.1 \%$ Triton $\mathrm{X}-100$ in $0.1 \mathrm{M} \mathrm{HCl}(400 \mu \mathrm{l})$. Cells were then scraped and ${ }^{3} \mathrm{H}$-IPs were isolated as previously described (El-Etr et al., 1989).

\section{Results}

\section{Glutamate-evoked release of ${ }^{3} \mathrm{H}$-AA from striatal astrocytes}

Cultured astrocytes preincubated for $18 \mathrm{hr}$ with ${ }^{3} \mathrm{H}$-AA incorporated $85-90 \%$ of the radioactivity. Striatal astrocytes released ${ }^{3} \mathrm{H}$-AA $\left(1-2 \%\right.$ of the cellular ${ }^{3} \mathrm{H}$ content) in the presence of glutamate $(2 \mathrm{mM})$. At the maximal concentration of glutamate used ( $2 \mathrm{~mm})$, the release of ${ }^{3} \mathrm{H}-\mathrm{AA}$ reached a plateau after 10 min of incubation (Fig. 1). Glutamate $\left(2 \mathrm{~mm}\right.$ ) released ${ }^{3} \mathrm{H}$-AA by $62 \% \pm 3, n=46$ (mean \pm SEM of results obtained in $n$ independent experiments) above basal level with an $\mathrm{EC}_{50}$ of 200 $\mu \mathrm{M} \pm 70(n=4)$. The Eadie-Hofstee's plot of the dose-response curve was linear (Hill coefficient, $1.01 \pm 0.02$ ), suggesting the involvement of only one type of noninteracting glutamate receptor (Fig. 2).

Interestingly, as previously described (Pcarce ct al., 1986; ElEtr et al., 1992), glutamate also stimulated the production of ${ }^{3} \mathrm{H}$-IPs in striatal astrocytes $(85 \% \pm 5$ above basal value, $n=$ 5). However, the Eadie-Hofstee's plot of the dose-response curve was biphasic (Hill coefficient, $0.80 \pm 0.01$ ), suggesting the involvement of two types of receptors displaying different affinities and efficacies. One of them had a high efficacy $(68 \% \pm 10$ of ${ }^{3} \mathrm{H}$-IP production) and could also have a high aflinity for glutamate $\left(\mathrm{EC}_{50}=25 \pm 10 \mu \mathrm{M}\right.$, as estimated from three independent 
Figure 2. Dose-response curves for the glutamate-evoked release of ${ }^{3} \mathrm{H}-\mathrm{AA}$ and were incubated for $15 \mathrm{~min}$ with increasing concentrations of glutamate $(S)$. Results are expressed as percentage of the responses $(V)$, that is, release of ${ }^{3} \mathrm{H}-\mathrm{AA}$ (C) or formation of ${ }^{3} \mathrm{H}$-IPs ( $\square$ ) estimated in the presence of glutamate. The Eadie-Hofstee's plots of each dose-response curve are shown in the inset. Data are the mean \pm SEM of three determinations. Two independent other experiments yielded similar results. ${ }^{3} \mathrm{H}-\mathrm{IP}$ formation. Striatal astrocytes

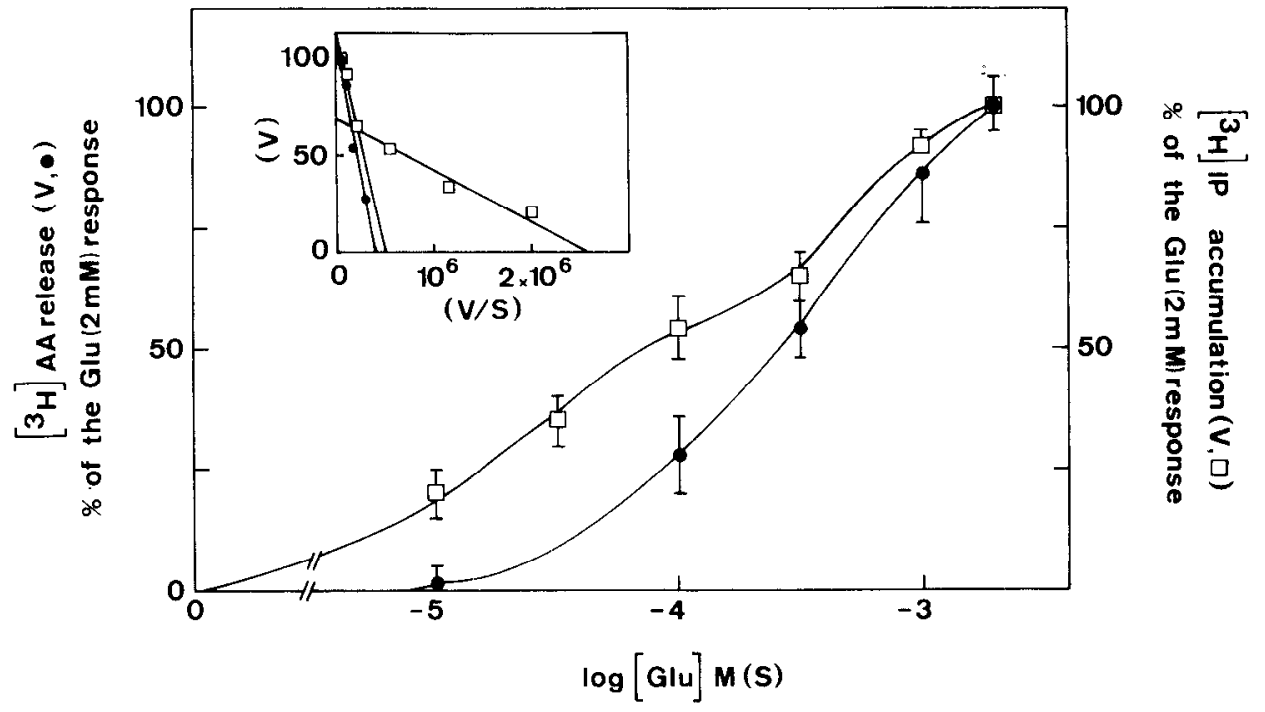

experiments) and the other a relative low efficacy $(43 \% \pm 7)$ and low affinity $\left(\mathrm{EC}_{50}=300 \pm 100 \mu \mathrm{M}\right)$ (Fig. 2).

Gutamate-evoked release of ${ }^{3} \mathrm{H}$-AA from astrocytes of different brain structures

As indicated in Table 1, the efficacy of glutamate (2 $\mathrm{mm})$ in rclcasing ${ }^{3} \mathrm{H}-\mathrm{AA}$ from astrocytes originating from the ccrebral cortex, the cerebellum, or the hippocampus was roughly similar to that observed with striatal astrocytes. Therefore, in the following experiments, the pharmacological specificity of the receptors involved in the glutamate-evoked release of ${ }^{3} \mathrm{H}-\mathrm{AA}$ was investigated in striatal astrocytes.

Comparison of the pharmacological properties of glutamate receptors involved in the release of ${ }^{3} \mathrm{H}-\mathrm{AA}$ or the formation of ${ }^{3} \mathrm{H}-I P S$

In agreement with previous observations (Milani et al., 1989) and confirming the absence of NMDA receptors on astrocytes,

Table 2. Effects of glutamatergic receptor agonists on either the release of ${ }^{3} \mathrm{H}$-AA or formation of ${ }^{3} \mathrm{H}$-IP in striatal astrocytes

\begin{tabular}{llcc} 
& & \multicolumn{2}{c}{$\%$ of the Glu $(2 \mathrm{mM})$ response } \\
\cline { 3 - 4 } Agonists & $\mathrm{mM}$ & ${ }^{3} \mathrm{H}$-AA release & $\begin{array}{l}{ }^{3} \mathrm{H}-\mathrm{IP} \\
\text { accumulation }\end{array}$ \\
\hline Glutamate & 2 & $100 \pm 5^{*}$ & $100 \pm 6^{*}$ \\
NMDA & 0.1 & $28 \pm 8^{*}$ & $54 \pm 7^{*}$ \\
Kainate & 0.1 & $0 \pm 6$ & $0 \pm 4$ \\
AMPA & 0.1 & $9 \pm 8$ & $10 \pm 5$ \\
& 0.1 & $13 \pm 6$ & $2 \pm 5$ \\
Ibotenate & 1 & $0 \pm 13$ & $8 \pm 4$ \\
Quisqualate & 1 & $13 \pm 8$ & $0 \pm 6$ \\
& 0.1 & $15 \pm 3$ & $152 \pm 5^{*}$ \\
$t$-ACPD & 1 & $40 \pm 6^{*}$ & $105 \pm 4^{*}$ \\
& 0.1 & $12 \pm 3$ & $3 \pm 3$ \\
& 1 & $8 \pm 10$ & $17 \pm 3$
\end{tabular}

Several agonists of ionotropic or metabotropic glutamatergic receptors were used at the indicated concentrations (mM). Results are expressed as percentage of the response measured in the presence of glutamate $(2 \mathrm{~mm})$. Data are the mean \pm SEM of three determinations. Two other independent experiments yielded similar results.

* Significantly different $(p<0.01)$ from the corresponding basal values (Student's $t$ test). even in the absence of external magnesium, NMDA $(100 \mu \mathrm{M})$ did not increase the release of ${ }^{3} \mathrm{H}-\mathrm{AA}$ or the formation of ${ }^{3} \mathrm{H}$ IPs in striatal astrocytes (Table 2). Moreover, the competitive and noncompetitive antagonists of NMDA receptors, AP5 (1 $\mathrm{mM}$ ) and MK801 ( $1 \mu \mathrm{M})$, respectively, did not suppress the effects of 2 mm glutamate (Fig. 3).

The presence of AMPA/kainate receptors has already been described on astrocytes from the cerebellum (Burnashev et al., 1992; Müller et al., 1992) or the cerebral cortex (Jensen and Chiu, 1991). However, neither AMPA (0.1 and $1 \mathrm{~mm}$ ) nor kainate $(0.1 \mathrm{~mm})$ stimulated the ${ }^{3} \mathrm{H}$-AA release or the ${ }^{3} \mathrm{H}-\mathrm{IP}$ accumulation in striatal astrocytes (Table 2). Moreover, these glutamate ( $2 \mathrm{~mm}$ )-evoked responses were not antagonized by CNQX (0.1 mm) or DNQX (0.1 mm) (Fig. 3). As AMPA or kainate, ibotenate (1 mM) was without effect on ${ }^{3} \mathrm{H}-\mathrm{AA}$ release or ${ }^{3} \mathrm{H}-\mathrm{IP}$ production (Table 2).

The stimulatory effect of glutamate $(2 \mathrm{~mm})$ on the ${ }^{3} \mathrm{H}-\mathrm{AA}$ release was strongly inhibited by AP3 (1 mM), a relative specific antagonist of metabotropic receptors (Schoepp et al., 1990) (Fig. $3)$. However, $t$-ACPD (1 mM), a selective agonist of the glutamate metabotropic receptors found in brain slices and on striatal neurons particularly (Manzoni et al., 1991), was ineffective in stimulating the release of ${ }^{3} \mathrm{H}-\Lambda \Lambda$ or the formation of ${ }^{3} \mathrm{H}-\mathrm{IPs}$ in striatal astrocytes (Table 2). This suggests that the glutamate metabotropic receptors of astrocytes were distinct from those of neurons.

In addition, two observations suggest that, in striatal astrocytes, the receptor subtype responsible for the glutamate-evoked release of ${ }^{3} \mathrm{H}-\mathrm{AA}$ is different from those involved in the formation of ${ }^{3} \mathrm{H}$-IPs: (1) AP4 (1 mM) antagonized the glutamateevoked release of ${ }^{3} \mathrm{H}$-AA but was ineffective in suppressing the formation of ${ }^{3} \mathrm{H}$-IPs (Fig. 3); (2) quisqualate ( $1 \mathrm{~mm}$ ) only weakly enhanced the release of ${ }^{3} \mathrm{H}-\mathrm{AA}$, whereas its stimulatory effect on the formation of ${ }^{3} \mathrm{H}$-IPs was identical to that of glutamate (2 mM) (Table 2). Moreover, when used at a lower concentration $(0.1 \mathrm{~mm})$, quisqualate was without effect on the ${ }^{3} \mathrm{H}$-AA release but, as already described in hippocampal slices from neonatal rats (Littman et al., 1992), it stimulated ${ }^{3} \mathrm{H}$-IP formation to a larger extent than that observed with $1 \mathrm{~mm}$ (Table 2).

Attempts were also made to look for possible differences in the pharmacological properties of the two putative receptors responsible for the formation of ${ }^{3} \mathrm{H}$-IPs using two concentrations of glutamate, $2 \mathrm{~mm}$ and $0.1 \mathrm{~mm}$. Indeed, at $0.1 \mathrm{~mm}$ glutamate 


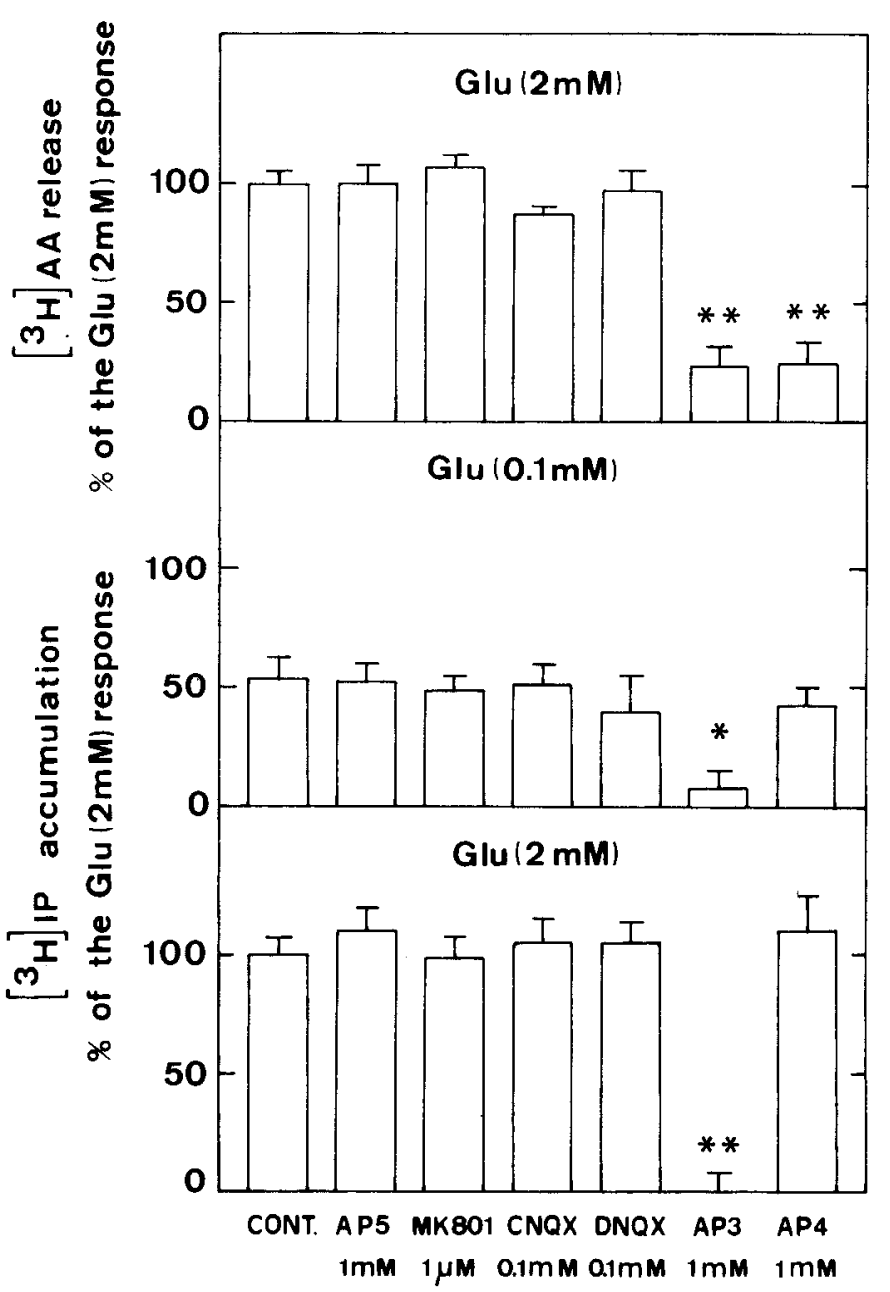

Figure 3. Effects of various glutamatergic receptor antagonists on the glutamate-evoked release of ${ }^{3} \mathrm{H}-\mathrm{AA}$ and ${ }^{3} \mathrm{H}$-IP formation. The potency of various antagonists of ionotropic or metabotropic glutamatergic receptors in inhibiting the glutamate-evoked release of ${ }^{3} \mathrm{H}$-AA or formation of ${ }^{3} \mathrm{H}$-IPs was measured in the presence of $2 \mathrm{~mm}$ or $0.1 \mathrm{~mm}$ glutamate in striatal astrocytes. Cells were preincubated for $10 \mathrm{~min}$ and then incubated with each antagonist. AP3 and AP4 slightly decreased the basal release of ${ }^{3} \mathrm{H}-\mathrm{AA}(10 \pm 1 \%$ and $9 \pm 3 \%$, respectively). The other antagonists had no significant effect on the basal release of ${ }^{3} \mathrm{H}$ AA. Results are expressed as percentage of the responses estimated in the presence of glutamate $(2 \mathrm{~mm})$. Data are the mean \pm SEM of three determinations. Two independent other experiments yielded similar results. Asterisks indicate data significantly different $\left({ }^{*}, p<0.05\right.$, and ${ }^{* *}, p<0.01$ ) from the corresponding control values (Student's $t$ test).

should mainly activate the receptor exhibiting the highest affinity $\left(\mathrm{EC}_{50}, 25 \mu \mathrm{M}\right)$. However, whatever the antagonist used, no difference could be observed in the pharmacological properties of these receptors.

Lack of involvement of the high-affinity glutamate transport in the glutamate-evoked release of ${ }^{3} \mathrm{H}-\mathrm{AA}$

The atypical pharmacological properties of the putative metabotropic receptors responsible for the glutamate-evoked release of ${ }^{3} \mathrm{H}$-AA led us to look for a possible role of the glutamate uptake process in this response. Hence, the effect of glutamate was tested in the presence of two different glutamate uptake inhibitors, $\beta$-MAA and $t$-PDC.

When used alone, the glutamate uptake inhibitors only partially reproduced the stimulatory effect of glutamate on the re-
Table 3. Lack of effect of sodium-dependent glutamate uptake inhibitors on the glutamate-induced release of ${ }^{3} \mathrm{H}-\mathrm{AA}$

\begin{tabular}{lllll} 
& & \multicolumn{3}{c}{${ }^{3} \mathrm{H}-\mathrm{AA}$ release (\% of basal) } \\
\cline { 2 - 5 } Conditions & Basal & $\begin{array}{l}\text { ( GPT } \\
\text { (10 IU) }\end{array}$ & Glu & Glu + \\
\hline Control & $100 \pm 5$ & $81 \pm 3^{*}$ & $165 \pm 5$ & GPT \\
$\beta$-MAA $(1 \mathrm{~mm})$ & $136 \pm 4$ & $80 \pm 4^{* *}$ & $165 \pm 4$ & $79 \pm 3^{* *}$ \\
$t$-PDC (1 mM) & $138 \pm 5$ & $82 \pm 4^{* *}$ & $160 \pm 5$ & $83 \pm 4^{* *}$ \\
Sucrose (240 mM) & $135 \pm 4$ & $80 \pm 5^{* *}$ & $188 \pm 8$ & $80 \pm 2^{* *}$ \\
NMDG (120 mM) & $140 \pm 5$ & $86 \pm 4^{* *}$ & $245 \pm 10$ & $88 \pm 1^{* *}$
\end{tabular}

The effect of glutamate ( $2 \mathrm{~mm}$ ) was estimated either in the presence of two different inhibitors of the high-affinity and sodium-dependent glutamate uptake, $\beta$-MAA $(1 \mathrm{mM})$ or $t$-PDC $(1 \mathrm{mM})$, or using a sodium-free incubating medium in which sodium was replaced by sucrose (240 mim) or the nonpermeant and monovalent cation NMDG (120 mm). The effect of enzymatic glutamate removal by GPT (10 $\mathrm{IU} / \mathrm{ml}$ ) in the presence of $1 \mathrm{~mm}$ pyruvate was tested in each condition. Data are the mean \pm SEM of three determinations. Two independent other cxpcriments yielded similar results. Asterisks indicate data significantly different $\left({ }^{*} p<0.05\right.$ and ${ }^{* *} p<0.01$ ) from corresponding ${ }^{3} \mathrm{H}$-AA release estimated in the absence of GPT (Student's $t$ test).

lease of ${ }^{3} \mathrm{H}$-AA (Table 3). This differs from that observed for the formation of ${ }^{3} \mathrm{H}$-IPs since, as already reported, similar responses were found in the presence of either glutamate or the glutamate uptake inhibitors (El-Etr et al., 1992). The stimulatory effects of $\beta$-MAA ( $1 \mathrm{mM}$ ) and $t$-PDC ( $1 \mathrm{mM})$ on the release of ${ }^{3} \mathrm{H}-\mathrm{AA}$ could be due to the accumulation of glutamate spontancously relcascd from astrocytes (Kimelberg et al., 1990; Pares-Herbute et al., 1988) since this response disappeared in the presence of GPT ( $10 \mathrm{IU} / \mathrm{ml})$, an enzyme that converts glutamate into alanine and $\alpha$-ketoglutarate in the presence of pyruvate ( 1 $\mathrm{mm})$. Supporting this hypothesis, glutamate (2 $\mathrm{mm})$ still increased ${ }^{3} \mathrm{H}$-AA release in the presence of the glutamate uptake inhibitors to a level similar to that observed in their absence (Table 3).

Altogether, these results suggest that the stimulatory effect of glutamate on ${ }^{3} \mathrm{H}$-AA release is not linked to the amino acid transport but rather to the extracellular activation of membrane receptors. This was further supported by experiments in which the high-affinity sodium-dependent glutamate uptake process was impaired by replacing sodium with either sucrose (240 mM) or the monovalent and nonpermeant cation $N$-methyl-D-glucamine (NMDG; $120 \mathrm{~mm}$ ). Indeed, under these conditions, glutamate ( $2 \mathrm{~mm}$ ) still increased the release of ${ }^{3} \mathrm{H}-\mathrm{AA}$. Moreover, in the presence of NMDG, the glutamate efficacy in releasing ${ }^{3} \mathrm{H}-\mathrm{AA}$ was improved (Table 3 ). The potentiating effect of NMDG could result from the large increase in intracellular cytosolic free calcium that occurs under this condition (Delumeau et al., 1991). Interestingly, the basal release of ${ }^{3} \mathrm{H}-\mathrm{AA}$ was significantly enhanced in the absence of external sodium. An accumulation of glutamate in the incubation medium could be involved in this latter phenomenon, since this response was decreased when glutamate was enzymatically eliminated by GPT. Finally, GPT alone (as well as AP3; see Fig. 3 caption) slightly but constantly reduced the basal level of ${ }^{3} \mathrm{H}-\mathrm{AA}$ release. This suggests that glutamate is present in low amounts in the incubation medium even under the control condition. Thimerosal was added in all experiments in order to inhibit the reacylation of AA (Hatzelmann et al., 1990). This could induce the accumulation of the unsaturated fatty acid in the plasma membrane, leading to a decreased reuptake of glutamate that in turn, could be accumulated in the incubation medium (Volterra et al., 1992). 
Table 4. Possible involvement of PLA, in the glutamate-induced release of ${ }^{3} \mathrm{H}-\mathrm{AA}$ from striatal astrocytes

\begin{tabular}{|c|c|c|c|c|}
\hline \multirow[b]{2}{*}{ Agents } & \multicolumn{2}{|c|}{$\%$ of basal ${ }^{3} \mathrm{H}-\mathrm{AA}$ release } & \multicolumn{2}{|c|}{$\begin{array}{l}\% \text { of basal }{ }^{3} \mathrm{H}-\mathrm{IP} \\
\text { accumulation }\end{array}$} \\
\hline & Basal & Glu (2 mM) & Basal & $\begin{array}{l}\text { Glu } \\
(2 \mathrm{~mm})\end{array}$ \\
\hline None & $100 \pm 5$ & $165 \pm 7^{*}$ & $100 \pm 4$ & $171 \pm 7^{*}$ \\
\hline $\begin{array}{c}\text { Mepacrine } \\
\qquad(20 \mu \mathrm{M})\end{array}$ & $82 \pm 3$ & $89 \pm 5$ & $115 \pm 8$ & $188 \pm 9^{*}$ \\
\hline $\begin{array}{l}\text { RG } 80267 \\
\quad(50 \mu \mathrm{M}) \\
\text { Without } \mathrm{Ca}^{2+}\end{array}$ & $\begin{array}{l}105 \pm 6 \\
117 \pm 13\end{array}$ & $\begin{array}{l}175 \pm 10^{*} \\
127 \pm 13\end{array}$ & $\begin{array}{l}97 \pm 8 \\
\text { ND }\end{array}$ & $\begin{array}{l}175 \pm 5^{*} \\
N D\end{array}$ \\
\hline
\end{tabular}

The effects of mepacrine, RG 80267, and the absence of external $\mathrm{Ca}^{2+}$ were tested on both the basal and the glutamate ( $2 \mathrm{~mm}$ )-induced release of ${ }^{3} \mathrm{H}$-AA and ${ }^{3} \mathrm{H}$ IP formation. Data are the mean \pm SEM of three determinations. Two independent other experiments yielded similar results. Asterisks indicate data significantly different (* $p<0.01$ ) from corresponding basal values (Student's $t$ test). ND, not determined.

\section{Lack of effect of PTX on the glutamate-evoked release of ${ }^{3} H-A A$}

In several cell types, the different receptors involved in the evoked release of AA are thought to be coupled to guanine nucleotide-binding proteins (G-proteins), which have often been found to be sensitive to PTX. However, when striatal astrocytes were incubated for $24 \mathrm{hr}$ with this toxin $(1 \mu \mathrm{g} / \mathrm{ml})$, both the basal and the glutamate-evoked release of ${ }^{3} \mathrm{H}-\mathrm{AA}$ remained unchanged (98 $\pm 7 \%$ and $167 \pm 9 \%$, respectively, of the basal value estimated in untreated cells, $n=4$ ).

\section{Possible involvement of a phospholipase $A_{2}$ activation in the} glutamate-evoked release of ${ }^{3} H-A A$

AA may be released following either the activation of a phospholipase $\mathrm{A}_{2}\left(\mathrm{PLA}_{2}\right)$ or the sequential actions of a phosphoinositide-specific phospholipase C (PLC) and a diacylglycerol lipase (Bell et al., 1979). Therefore, mepacrine and RG 80267, a nonspecific $\mathrm{PLA}_{2}$ inhibitor and a diacylglycerol lipase inhibitor, respectively, were used to identify the enzyme responsible for the glutamate-evoked release of ${ }^{3} \mathrm{H}-\mathrm{AA}$.

As observed by Lazarewicz et al. (1992) on cerebellar neurons, mepacrine $(20 \mu \mathrm{M})$, which only slightly altered the glutamate-

\section{Table 5. Role of cAMP in the glutamate-induced release of 'II-AA from striatal astrocytes}

\begin{tabular}{|c|c|}
\hline Agonists & $\begin{array}{l}{ }^{3} \mathrm{H}-\mathrm{AA} \\
\text { release } \\
{[\% \text { of the Glu }} \\
(2 \mathrm{~mm}) \\
\text { response] }\end{array}$ \\
\hline Glutamate (2 mM) & $100 \pm 5$ \\
\hline$+8-\mathrm{Br}-\mathrm{cAMP}(0.1 \mathrm{~mm})$ & $53 \pm 6^{*}$ \\
\hline$+\operatorname{VIP}(1 \mu \mathrm{M})$ & $51 \pm 6^{*}$ \\
\hline+ Iso $(20 \mu \mathrm{M})$ & $53 \pm 11^{*}$ \\
\hline$+\operatorname{CTX}(3 \mu \mathrm{g} / \mathrm{ml})$ & $62 \pm 11^{*}$ \\
\hline
\end{tabular}

The glutamate ( $2 \mathrm{~mm}$ )-induced release of ${ }^{3} \mathrm{H}-\mathrm{AA}$ was tested in the presence of isoproterenol (Iso), VIP, 8-Br-cAMP, or using cells pretreated for $18 \mathrm{hr}$ with CTX. Results are expressed as percentage of the responses estimated in the presence of glutamate $(2 \mathrm{mM})$. Data are the mean \pm SEM of three determinations. Two independent other experiments yielded similar results. Asterisks indicate data significantly different $\left({ }^{*} p<0.05\right)$ from the response estimated in the presence of glutamate alone (Student's $t$ test).

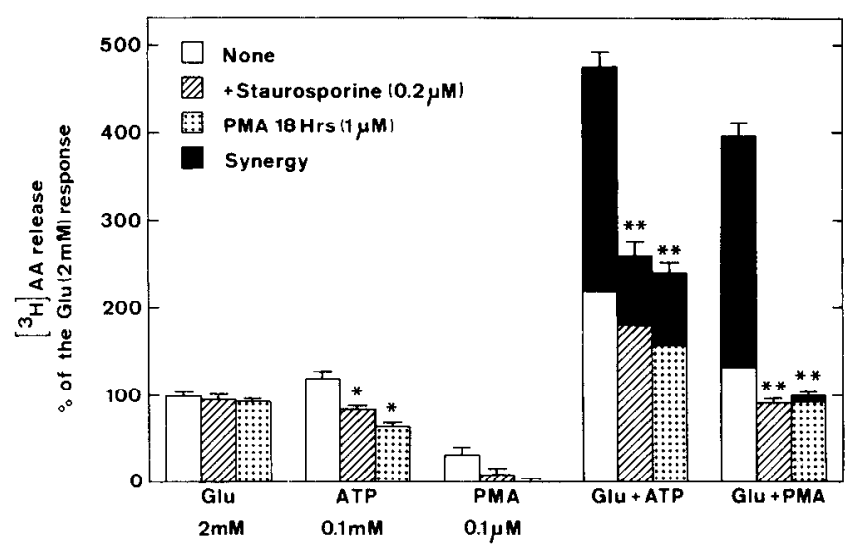

Figure 4. Role of PKC in the glutamate-induced release of ${ }^{3} \mathrm{H}-\mathrm{AA}$. The release of ${ }^{3} \mathrm{H}-\mathrm{AA}$ was estimated in the presence of glutamate, ATP, glutamate + ATP, PMA, or Glu + PMA, either in the presence or absence of staurosporine ( $10 \mathrm{~min}$ preincubation) or using cells pretreated for $18 \mathrm{hr}$ with PMA. Results are expressed as percentage of the responses measured in the presence of glutamate $(2 \mathrm{~mm})$. The synergistic component (Synergy) was calculated as the difference between the level of ${ }^{3} \mathrm{H}-\mathrm{AA}$ release measured in the co-presence of glutamate and ATP or PMA and the arithmetic sum of the effect of each effector added separately. Data are the mean \pm SEM of three determinations. Two independent other experiments yielded similar results. Asterisks indicate data significantly different $\left({ }^{*}, p<0.05\right.$, and $\left.{ }^{* *}, p<0.01\right)$ from the level of ${ }^{3} \mathrm{H}-\mathrm{AA}$ release estimated in the absence of staurosporine or from cells not pretreated with PMA for $18 \mathrm{hr}$ (Student's $t$ test).

induced formation of ${ }^{3} \mathrm{H}-\mathrm{IPs}$, almost completely suppressed the glutamate-evoked release of ${ }^{3} \mathrm{H}$-AA from striatal astrocytes. $\mathrm{RG}$ $80267(50 \mu \mathrm{M})$ was ineffective on both responses (Table 4).

Supporting further an involvement of a PLA $\mathrm{P}_{2}$, an enzyme highly sensitive to calcium (Burch, 1989), glutamate (2 $\mathrm{mm}$ ) failed to stimulate the release of ${ }^{3} \mathrm{H}-\mathrm{AA}$ when striatal astrocytes were incubated in a calcium-free buffer (Table 4).

\section{Role of protein kinases in the glutamate-evoked release of ${ }^{3} H-A A$}

As shown in various cell types, different protein kinases and, particularly, the cAMP-dependent protein kinase (PKA) and protein kinase $\mathrm{C}$ (PKC) can modulate the phospholipase activity responsible for the release of AA by different mechanisms.

In striatal astrocytes, changes in protein kinase activities did not seem to be required for the glutamate-evoked release of ${ }^{3} \mathrm{H}$ AA. Indeed, both a nonspecific inhibitor of protein kinases such as $\mathrm{H} 7(100 \mu \mathrm{M})$ and a relatively specific inhibitor of PKA, H8 (100 $\mu \mathrm{M})$, did not suppress the glutamate (2 $\mathrm{mm}$ )-evoked response but rather increased the release of ${ }^{3} \mathrm{H}-\mathrm{AA}$ induced by the amino acid $(37 \pm 5$ and $74 \pm 7 \%, n=4$, increase, respectively). This suggests that PKA exerts a negative control on this response. This hypothesis was further supported by experiments performed with agonists of receptors present on astrocytes and positively coupled to adenylate cyclase. Indeed, the stimulatory effect of glutamate on ${ }^{3} \mathrm{H}$-AA release was reduced in the presence of VIP $(1 \mu \mathrm{M})$ or of isoproterenol $(20 \mu \mathrm{M})$, an agonist of $\beta$-adrenergic receptors (Table 5). Moreover, the sustained activation of adenylate cyclase by a pretreatment of striatal astrocytes with CTX $(3 \mu \mathrm{g} / \mathrm{ml}$ for $18 \mathrm{hr})$ and the addition into the incubation medium of the membrane-permeant cAMP analog 8-Br-cAMP $(100 \mu \mathrm{M})$ decreased the glutamate-evoked release of ${ }^{3} \mathrm{H}-\mathrm{AA}$ (Table 5$)$.

In contrast to the inhibitory effect of PKA, additional experiments suggested that PKC could improve the glutamate-evoked 
release of ${ }^{3} \mathrm{H}-\mathrm{AA}$. Indeed, the stimulatory effect of glutamate was synergistically enhanced by $\operatorname{PMA}(0.1 \mu \mathrm{M})$, an exogenous activator of $\mathrm{PKC}$, since the amplitude of the response was higher than the sum of the responses induced separately by each effector. The enhancing action of PMA on the glutamate-evoked release of ${ }^{3} \mathrm{H}$-AA was markedly decreased in either the presence of a relatively specific inhibitor of $\mathrm{PKC}$, staurosporine $(0.2 \mu \mathrm{M})$, or when astrocytes were pretreated for $18 \mathrm{hr}$ with PMA $(1 \mu \mathrm{M})$ to desensitize PKC (Fig. 4). In contrast to PMA, the inactive isomer $4 \alpha$-PMA $(0.1 \mu \mathrm{M})$ did not modify the glutamate-evoked release of ${ }^{3} \mathrm{H}-\mathrm{AA}$ (data not shown).

Finally, PKC was activated more physiologically by stimulating PLC activity. Hence, ATP $(0.1 \mathrm{~mm})$ was used since it strongly stimulated the formation of ${ }^{3} \mathrm{H}$-IPs in striatal astrocytes $(380 \% \pm 20$ of the basal level). $\Lambda$ s expected, the glutamate ( 2 mM)-evoked release of ${ }^{3} \mathrm{H}$-AA was synergistically enhanced by ATP $(0.1 \mathrm{~mm})$, the amplitude of this response being similar to that observed with PMA. In addition, the synergistic effect of ATP $(0.1 \mathrm{mM})$ was largely decreased by staurosporine $(0.2 \mu \mathrm{M})$ or when astrocytes were pretreated for $18 \mathrm{hr}$ with PMA $(1 \mu \mathrm{M})$. Altogether, these observations strongly suggest that activation of PKC potentiates the glutamate-evoked release of ${ }^{3} \mathrm{H}-\mathrm{AA}$ from striatal astrocytes.

\section{Discussion}

In astrocytes from various brain structures, glutamate enhances phosphoinositide breakdown by acting on metabotropic receptors and raises the intracellular concentration of free ionized calcium by stimulating both metabotropic and ionotropic receptors (Pearce et al., 1986; Glaum et al., 1990). In addition, as demonstrated in the present study, glutamate also stimulates the release of ${ }^{3} \mathrm{H}$-AA from astrocytes by acting on metabotropic receptors that appear to be pharmacologically different from those involved in the activation of PLC.

Our results differ from those of Oomagari et al. (1991), since these authors failed to observe a glutamate-evoked release of ${ }^{3} \mathrm{H}$-AA from astrocytes. This could be due to the absence of thimcrosal in thcir incubation medium since, in the absence of this compound, we were also unable to observe the stimulatory effect of glutamate on ${ }^{3} \mathrm{H}-\mathrm{AA}$ release from striatal astrocytes. The mechanism by which thimerosal unmasks the glutamateevoked release of ${ }^{3} \mathrm{H}-\mathrm{AA}$ is still unknown, although its inhibitory action on the acyl-CoA: lysophosphatidylcholine-acyl-transferase (Hänsch et al., 1985) could be involved in this effect. The fatty acid-free BSA, which is added to the incubation medium to trap released ${ }^{3} \mathrm{H}-\mathrm{AA}$, should also prevent reacylation, such an effect being reinforced by thimerosal. Thimerosal has also been shown to increase the concentration of cytosolic calcium in different cell types (Bootman et al., 1992). However, the intervention of this mechanism is unlikely, since the calcium ionophore ionomycin $(2 \mu \mathrm{M})$ did not reproduce the unmasking effect of thimerosal on the glutamate-evoked response, although at this concentration ionomycin induced an increase in cytosolic calcium of similar amplitude (about $250 \mathrm{~nm}$ ) to that observed in the presence of $50 \mu \mathrm{M}$ thimerosal (data not shown).

The involvement of ionotropic receptors in the glutamateevoked release of ${ }^{3} \mathrm{H}-\mathrm{AA}$ or production of ${ }^{3} \mathrm{H}$-IPs in striatal astrocytes can be ruled out, since neither the agonists nor the antagonists of NMDA or AMPA/kainate ionotropic receptor subtypes reproduced or suppressed the effects of glutamate.

Several observations suggest that the metabotropic receptors involved in the glutamate-evoked release of ${ }^{3} \mathrm{H}$-AA are different from those responsible for the formation of ${ }^{3} \mathrm{H}$-IPs. Indeed, the dose-response curve for the glutamate-evoked formation of ${ }^{3} \mathrm{H}$ IPs was biphasic (its main component showing the lowest $\mathrm{EC}_{50}$ value, $25 \mu \mathrm{M}$ ) while that corresponding to the release of ${ }^{3} \mathrm{H}-\mathrm{AA}$ was monophasic. In addition, in spite of the similarity of the $\mathrm{EC}_{50}$ values (about $300 \mu \mathrm{M}$ ) of the second component of the glutamate-evoked formation of ${ }^{3} \mathrm{H}$-IPs and of the single component of the glutamate-evoked release of ${ }^{3} \mathrm{H}-\Lambda \Lambda\left(\mathrm{EC}_{50}\right.$ value, $200 \mu \mathrm{M})$, the receptors involved in these two responses appeared to be different. First, when used at a low concentration ( $0.1 \mathrm{~mm})$, quisqualate induced a higher formation of ${ }^{3} \mathrm{H}-\mathrm{IPs}$ than glutamate ( $2 \mathrm{~mm}$ ) while, in contrast to glutamate, it only weakly stimulated ${ }^{3} \mathrm{H}$-AA release when used either at $0.1 \mathrm{~mm}$ or $1 \mathrm{~mm}$. The higher efficacy of quisqualate at 0.1 than at $1 \mathrm{~mm}$ in enhancing ${ }^{3} \mathrm{H}-\mathrm{IP}$ formation could be attributed to a desensitization of the response at the higher concentration. Second, although the antagonist AP3 suppressed both responses, AP4 specifically inhibited the glutamate-evoked release of ${ }^{3} \mathrm{H}-\mathrm{AA}$ but was without effect on the glutamate-induced formation of ${ }^{3} \mathrm{H}$-IPs. Interestingly enough, the glutamatergic receptors responsible for both the release of ${ }^{3} \mathrm{H}-\mathrm{AA}$ and the production of ${ }^{3} \mathrm{H}$-IPs were not activated by $\iota$-ACPD or ibotenate. Altogether, these pharmacological properties indicate that these receptors do not belong to the family of the already cloned metabotropic receptors (Nakanishi, 1992).

Astrocytes possess a broad array of receptors coupled to different intracellular signaling pathways. For instance, we have previously reported that the selective $\beta$-adrenergic agonist isoproterenol and VIP induced a large production of cAMP in cultured striatal astrocytes from mouse embryos (Chneiweiss et al., 1985). In addition, as shown in this study, ATP by acting on purinergic receptors, possibly of the $\mathrm{P} 2$ subtype (Kastritsis et al., 1992), stimulated the formation of ${ }^{3} \mathrm{H}$-IPs to a much larger extent than that observed with glutamate or the $\alpha_{\mathrm{i}}$-adrenergic agonist methoxamine (Marin et al., 1991; El-Etr et al., 1992). This led us to investigate whether the glutamate-evoked release of ${ }^{3} \mathrm{H}$-AA could be modulated by changes in the cAMP or phosphoinositide signaling pathways using the most potent agonists of receptors coupled to those second messenger-generating systems.

Several observations suggested that PKA activity was involved in a negative control of the glutamate-evoked release of ${ }^{3} \mathrm{H}-\mathrm{AA}:(1)$ the nonspecific protein kinase inhibitors $\mathrm{H} 7$ or $\mathrm{H} 8$ significantly potentiated the glutamate response, indicating that a protein kinase activity could exert a tonic inhibitory action on this response; (2) isoproterenol and VIP reduced the glutamate respoinse; and finally, (3) similar inhibitory effects on the glutamate-evoked release of ${ }^{3} \mathrm{H}-\mathrm{AA}$ were seen when $\mathrm{PKA}$ activity was enhanced by exposing striatal astrocytes to 8-Br-cAMP or pretreating them with CTX.

On the contrary, PKC activity seems to be involved in a positive control of the glutamate-evoked release of ${ }^{3} \mathrm{H}-\mathrm{AA}$ : (1) the exogenous activator of PKC, namely PMA, which alone was effective, syncrgistically enhanced the glutamate response, and this effect was reduced either in the presence of staurosporine, an inhibitor of $\mathrm{PKC}$, or by pretreating the astrocytes for $18 \mathrm{hr}$ with PMA to desensitize PKC; (2) similarly, as observed for PMA, ATP, which alone was effective, potentiated the glutamate-evoked response, and this potentiating effect was also markedly reduced by staurosporine or following the $18 \mathrm{hr}$ pretreatment of the cells with PMA. Using purified cytosolic PLA, Lin et al., (1993) have also concluded that PKC was involved 
in the regulation of PLA $\mathrm{A}_{2}$. However, these authors demonstrated that PLA $\mathrm{P}_{2}$ is the substrate of MAP kinase and that this kinase is regulated by $\mathrm{PKC}$. The rise in cytosolic calcium resulting from the activation of glutamate or ATP receptors (Glaum et al., 1990; Jensen and Chiu, 1991; Kastritsis et al., 1992) could also be involved both in their own effects and in their synergistic stimulation of the release of ${ }^{3} \mathrm{H}-\mathrm{AA}$. Indeed, the translocation of the cytosolic $\mathrm{PLA}_{2}$ to the plasma membrane that contains the phospholipid substrate requires an increase in cytosolic calcium (Channon and Leslie, 1990).

We have previously shown that striatal astrocytes can release AA following the combined activation of either $\mathrm{Al}$ adenosine or somatostatin receptors and $\alpha_{1}$-adrenergic receptors. AA seems to block the reuptake of glutamate spontaneously released from the cclls, lcading thus to an accumulation of the amino acid in the external medium and subsequently to an activation of metabotropic receptors coupled to PLC (Marin et al., 1991; El-Etr et al., 1992). This sequence of events has been proposed to explain the apparent potentiation by adenosine or somatostatin of the methoxamine-induced formation of IPs in striatal astrocytes. As indicated by the present data, glutamate alone stimulates the release of AA, suggesting that it could regulate its own reuptake process. However, this regulation may only occur when relatively high concentrations of glutamate are present in the external medium since the metabotropic glutamatergic receptors involved have a very low affinity for glutamate.

The synergistic action of ATP and glutamate on the release of ${ }^{3} \mathrm{H}-\mathrm{AA}$ may have important physiological consequences, considering the anatomical organization of the striatum. Indeed, glutamate originates mainly from the nerve terminals of the cortico-striatal glutamatergic neurons that innervate the medium-sized spiny GABAergic efferent striatal neurons. Moreover, ATP is released with ACh from the cholinergic interneurons (Richardson and Brown, 1987), which also contact the GABAergic neurons. Preliminary results indicate that the NMDA-evoked release of AA from striatal neurons (Dumuis et al., 1988), which are mostly GABAergic, is markedly potentiated by the cholinergic agonist, carbachol (Tencé et al., 1993). Since ATP, the cotransmitter of ACh, synergistically enhances the glutamate-evoked release of AA from astrocytes, the combined activation of the cholinergic interneurons and corticostriatal glutamatergic neurons must lead to the formation of "hot spot" of AA in their cellular targets, that is, the neurons and the neighboring astrocytes. This phenomenon should singularly reinforce glutamatergic transmission since, as already indicated, AA inhibits glutamate reuptake into astrocytes and potentiates the NMDA-evoked current in neurons (Barbour et al., 1989; Miller et al., 1992).

\section{References}

Barbour B, Szatkowski M, Ingledew N, Attwell D (1989) Arachidonic acid induces a prolonged inhibition of glutamate uptake into glial cells. Nature 342:918-920.

Bell RL, Kennerly DA, Stanford N, Majerus PW (1979) Diglyceride lipase: a pathway for arachidonate release from platelets. Proc Natl Acad Sci USA 76:3228-3241.

Bootman MD, Taylor CW, Berridge M (1992) The thiol reagent, thimerosal, evokes $\mathrm{Ca}^{2+}$ spikes in HeLa cells by sensitizing the inositol 1,4,5-triphosphate receptor. J Biol Chem 35:25113-25119.

Burch RM (1989) $G$ protein regulation of phospholipase $A_{2}$. Mol Neurobiol 3:155-171.

Burnashev N, Khodorova A, Jonas P, Helm PJ, Wisden W, Monyer H, Seeburg PH, Sakmann B (1992) Calcium-permeable AMPA- kainate receptors in fusiform cerebellar glial cells. Science 256:15661570.

Channon JY, Leslie CC (1990) A calcium-dependent mechanism for associating a soluble arachidonoyl-hydrolyzing phospholipase $A_{2}$ with membrane in the macrophage cell line RAW 264. J Biol Chem 265: 5409-5413.

Chnciwciss H, Glowinski J, Prémont J (1985) Vasoactive intestinal polypeptide receptors linked to an adenylate cyclase, and their relationship with biogenic amine- and somatostatin-sensitive adenylate cyclases on central neuronal and glial cells in primary cultures. J Neurochem 44:779-786.

Delumeau JC, Tencé M, Marin P, Cordier J, Glowinski J, Premont J (1991) Synergistic regulation of cytosolic $\mathrm{Ca}^{2+}$ concentration by adenosine and $\alpha 1$-adrenergic agonists in mouse striatal astrocytes. Eur J Neurosci 3:539-550.

Dumuis A, Sebben M, Haynes L, Pin J-P, Bockaert J (1988) NMDA receptors activate the arachidonic acid cascade in striatal neurons. Nature 336:68-70.

El-Etr M, Cordier J, Glowinski J, Prémont J (1989) A neuroglial cooperativity is required for the potentiation by 2 -chloroadenosine of the muscarinic-sensitive phospholipase $\mathrm{C}$ in the striatum. J Neurosci 9:1473-1480.

El-Etr M, Marin P, Tencé M, Delumeau JC, Cordier J, Glowinski J, Premont J (1992) 2-Chloroadenosine potentiates the alpha 1 -adrenergic activation of phospholipase $\mathrm{C}$ through a mechanism involving arachidonic acid and glutamate in striatal astrocytes. J Neurosci $12: 1363-1369$.

Eng LF (1985) Glial fibrillary acid protein (GFAP): the major protein of glial intermediate filaments in differentiated astrocytes. J Neuroimmunol 8:203-214.

Enkvist KMO, Holopainen I, Akerman KEO (1989) $\alpha$-Receptor and cholinergic receptor-linked changes in cytosolic $\mathrm{Ca}^{2+}$ and membrane potential in primary rat astrocytes. Brain Res 500:46-54.

Frei K, Siepl C, Groscurth P, Bodmer S, Schwerdel C, Fontana A (1987) Antigen presentation and tumor cytotoxicity by interferon- $\gamma$-treated microglial cells. Eur J Immunol 17:1271-1278.

Glaum SR, Holzwarth JA, Miller RJ (1990) Glutamate receptors activate $\mathrm{Ca}^{2}$ mobilization and $\mathrm{Ca}^{2}$ influx into astrocytes. Proc Natl Acad Sci USA 87:3454-3458.

Hänsch GM, Gemsa D, Resch K (1985) Induction of prostanoid synthesis in human platelets by the late complement components C5b-9 and channel forming antibiotic nystatin: inhibition of the reacylation of liberated arachidonic acid. J Immunol 135:1320-1324.

Hatzelmann A, Haurand M, Ullrich V (1990) Involvement of calcium in the thimerosal-stimulated formation of leukotriene by PMLP in human polymorphonuclear leukocytes. Biochem Pharmacol 39:559567.

Jensen AB, Chiu SY (1991) Differential intracellular calcium responses to glutamate in type 1 and type 2 cultured brain astrocytes. J Neurosci $11: 1674-1684$.

Kastritsis CH, Sam AK, McCarthy KD (1992) Stimulation of the P2Y purinergic receptor on type 1 astroglia results in inositol phosphate formation and calcium mobilization. J Neurochem 58:1277-1284.

Kimelberg HK, Goderie SK, Higman S, Pang S, Waniewski RA (1990) Swelling-induced release of glutamate, aspartate and taurine from astrocytes in cultures. J Neurosci 10:1583-1591.

Lazarewicz J.W, Salinska E, Wroblewski JT (1992) NMDA receptormediated arachidonic acid release in neurons: role in signal transduction and pathological aspects. In: Neurobiology of essential fatty acids (Bazan NG, ed), pp 73-89. New York: XXXX.

Lin LL, Wartmann M, Lin AY, Knopf JL, Seth AS, Davis RJ (1993) $\mathrm{cPLA}_{2}$ is phosphorylated and activated by MAP kinase. Cell $72: 269-$ 278.

Littman L, Munir M, Flagg SD, Robinson MB (1992) Multiple mechanisms for inhibition of excitatory amino acid receptors coupled to phosphoinositide hydrolysis. J Neurochem 59:1893-1904.

Manzoni O, Poulat F, Do E, Sahuquet A, Sassetti I, Bockaert J, Sladeczek F (1991) Pharmacological characterization of the quisqualate receptor coupled to phospholipase C (Qp) in striatal neurons. Eur J Pharmacol 207:231-241.

Marin P, Delumeau JC, Tencé M, Cordier J, Glowinski J, Prémont J (1991) Somatostatin potentiates the alpha 1 -adrenergic activation of phospholipase $\mathrm{C}$ in striatal astrocytes through a mechanism involving arachidonic acid and glutamate. Proc Natl Acad Sci USA 88:90169020 . 
Martin DL (1992) Synthesis and release of neuroactive substances by glial cells. Glia 5:81-94.

Milani D, Facci L, Guidolini D, Leon A, Skaper S (1989) Activation of polyphosphoinositide metabolism as a signal-transducing system coupled to excitatory amino acid receptors in astroglial cells. Glia 2:161-169.

Miller B, Sarantis M, Traynelis SF, Attwell D (1992) Potentiation of NMDA receptor currents by arachidonic acid. Nature 355:722-725.

Müller T, Möller T, Berger T, Schnitzer J, Kettenmann H (1992) Calcium entry through kainate receptors and resulting potassium-channel blockade in Bergmann glial cells. Science 256:1563-1566.

Murphy S, Pearce B (1987) Functional receptors for neurotransmitters on astroglial cells. Neuroscience 22:381-394.

Nakanishi S (1992) Molecular diversity of glutamate receptors and implications for brain function. Science 258:597-603.

Newman EA (1991) Sodium bicarbonate cotransport in retinal Müller (glial) cells of the salamander. J Neurosci 11:3972-3983.

Newman EA, Frambach DA, Odette LL (1984) Control of extracellular potassium levels by retinal glial cell $\mathrm{K}^{+}$siphoning. Science $225: 1174$ 1175.

Nowak L, Ascher P, Berwald-Netter H (1987) Ionic channels in mouse astrocytes in culture. J Neurosci 7:101-109.

Oomagari K, Buisson B, Dumuis A, Bockaert J, Pin J-P (1991) Effect of glutamate and ionomycin on the release of arachidonic acid, prostaglandins and HETEs from cultured neurons and astrocytes. Eur J Neurosci 3:928-939.
Pares-Herbuté N, Bonet A, Peraldi S, Pin J-P, Gabrion J, Astier H, Tapia-Arancibia L (1988) The presence of non-neuronal cells influences somatostatin release from cultured cerebral cortical cells. Dev Brain Res 40:89-97.

Pearce B, Albrecht J, Morrow C, Murphy S (1986) Astrocyte glutamate receptor activation promotes inositol phospholipid turnover and calcium flux. Neurosci Lett 72:335-340.

Richardson PJ, Brown SJ (1987) ATP release from affinity-purified rat cholinergic nerve terminals. J Neurochem 48:622-630.

Schoepp DD, Johnson BG, Smith ECR, McQuaid LA (1990) Stereoselectivity and mode of inhibition of phosphoinositide-coupled excitatory amino acid receptors by 2-amino-3-phosphonopropionic acid. Mol Pharmacol 38:222-228.

Teichberg VI (1991) Glial glutamate receptors: likely actors in brain signaling. FASEB J 5:3086-3091.

Tencé M, Cordier J, Glowinski J, Prémont J (1992) Endothelin-evoked release of arachidonic acid from mouse astrocytes in primary culture. Eur J Neurosci 4:993-999.

Tencé M, Stella N, Cordier J, Prémont J, Glowinski J (1993) Muscarinic agonists induce a release of arachidonic acid from neurons in primary culture. J Neurochem [Suppl] 61:523.

Volterra A, Trotti D, Cassutti P, Tromba C, Salvaggio A, Melcangi RC, Racagni G (1992) High sensitivity of glutamate uptake to extracellular free arachidonic acid levels in rat cortical synaptosomes and astrocytes. J Neurochem 59:600-606. 